\title{
Implementation of strategic cost management in manufacturing companies: overcoming costs stickiness and increasing corporate sustainability
}

\author{
Mohammad Mahdi Rounaghi ${ }^{*} \mathbb{D}$, Hajer Jarrar² and Leo-Paul Dana ${ }^{3}$
}

\begin{abstract}
In today's competitive world, three factors: price, quality and time have critical roles in the success of the companies to achieve success in the competition. For this purpose, the companies have to also adapt themselves to changes in technology and environment. Strategic cost management is the best way to improve the sustainable management models in the manufacturing companies. Strategic cost management has solved many of the problems and shortcomings of traditional accounting system and by accurate determination of costs, their proper allocation to products and elimination of waste, tries to create value for shareholders by using continuous improvement. The objective of this paper was to develop a management model called strategic cost management that reduced costs stickiness and increased corporate sustainability. Using strategic cost management approach can create competitive advantage for the companies, because it provides accurate cost price information so that the users can easily understand the information. The aim of the paper by introducing strategic cost management was to contribute toward accurate pricing, which could result in the increased profitability and competitiveness of the manufacturing companies in a highly competitive global market and at a market-based price. Also, due to the growing competition among companies in providing high quality products with reasonable prices, a precise system of measurement of the cost of the product is necessary.
\end{abstract}

Keywords: Strategic cost management, Manufacturing companies, Cost stickiness, Corporate sustainability, Continuous improvement

\section{Introduction}

In recent years, economic analysis in the planning process and in the monitoring process of the production process shows that three factors: price, quality and time have critical roles in the success of the companies to achieve success in the competition. The world faces the problem of integration between sustained business functions. The sustainability data are not sufficiently integrated. To solve

\footnotetext{
*Correspondence: mahdi_rounaghi@yahoo.com

${ }^{1}$ Independent Researcher, Mashhad, Iran

Full list of author information is available at the end of the article
}

this problem, organizations need information systems to facilitate their sustainability initiatives [1,2]. Also, businesses and academics worldwide agree regarding the benefits of sustainable development (SD). Improving reputation and branding and increasing revenues by reducing costs are the primary strategic objectives of any entity $[3,4]$. In this paper, we introduce the strategic cost management approach that helps manufacturing companies for overcoming the costs stickiness and monitoring the life cycle of products and it introduces integrated sustainable development system for manufacturing companies.

Strategic cost management is a process connecting financial management, cost management and strategic 
management. It involves cost optimization and financial resources preparation which are needed to achieve desired strategic market position in cost effective manner. The importance of managing costs and aligning them with the business strategy of an entity is critical especially in the midst of challenging economic times faced by businesses today. Traditionally companies have been under pressure to cut cost in the short-term without really thinking about sustainable change, impact on the people and integration with the overall business strategy. In the current business environment of increased global competition, new markets, increasing regulation and changing demographics, successful companies are changing their approach to cost structuring and control.

Over the last decade, research in management accounting has challenged the fundamental assumption that cost behavior is symmetric for activity increases and decreases. Cost behavior is an important issue in cost accounting and management accounting, as it widely affects decision-making processes. Moreover, several techniques generally used by managerial accountants and financial analysts depend mainly on cost behavior, such as conventional $\mathrm{ABC}$, cost estimation and cost-volumeprofit analysis. Quality management (QM) has been widely viewed as a management paradigm that enables firms to gain a competitive. Therefore, overcoming on cost stickiness is a critical issue for mangers of manufacturing companies. Also, understanding cost behavior is an essential element of cost and management accounting [5-8].

Cost stickiness, also referred to as asymmetric cost behavior, is a well-documented result of managerial discretion underlying the development of corporate cost compared to changes in firm activity. Managers' decisions to maintain the resource allocations due to product market competition can be costly, especially during periods of sales decreases. Under the traditional model of cost behavior, costs are assumed to be either fixed or move proportionately and symmetrically with sales changes. The traditional model of cost behavior distinguishes between fixed and variable costs and posits a proportional relation between variable costs and underlying activity levels. Understanding sticky cost behavior is important and has direct benefits for the economy as it provides useful information to managers making decisions on cost control and to external stakeholders (e.g., financial analysts) assessing firm performance. As the global economy integrates and competes, strengthening cost management and operational efficiency becomes increasingly important to firms' survival and development [9-14].

Cost management is an important part of business management in the manufacturing industry. The degree of cost management implementation is a comprehensive index to measure the level of enterprise management. In particular, firms with limited access to capital have higher costs of securing external financing during the capacity expansion periods, which increases the upward adjustment costs. When activity decreases, firms with limited access to capital may suffer more decrease in the present value of revenue generated by a marginal capacity, as these firms have higher opportunity cost of capital and thus higher discount rates compared to firms with better access to capital. Therefore, we hypothesize that limited access to capital not only reduces contemporary capacity expansions associated with sales increases, but also weakens the degree of cost stickiness when sales decrease $[15,16]$.

On the other hand, cost management is an important part of business management in the manufacturing industry. The degree of cost management implementation is a comprehensive index to measure the level of enterprise management. From investors' perspective, investors depend on the published financial statements prepared by the management that are based on available information regarding the determinants of cost behavior. From financial analysts' perspective, predicting cost behavior is an essential part of earnings prediction [16-18].

In many production firms, it is common practice to financially reward managers for firm performance improvement. For decades, firms have devoted to improving the speed and efficiency of material and information flows in the supply chain, acknowledging the importance of time-based competitive advantage in the dynamic business environment. As one of the key factors in decision-making process, the evolution of product price passes critical information. Managing costs by utilizing resources effectively is regarded as fundamental to success in today's competitive environment. Cost behavior as "sticky" if costs increase more for activity increases than they decrease for an equivalent activity decrease. Sticky behavior is the result of decisions made by managers when activity decreases. When activity drops, the manager must decide whether to (a) maintain committed resources and bear the cost of unutilized capacity at least in the short-term or (b) immediately reduce committed resources and incur potentially large retrenching costs in the current period and, if activity increases in the future, incur further costs to replace resources. Traditional accounting cost models assume that fixed costs are independent of the level of activity and variable costs change proportionately with changes in the level of activity. In the common traditional model of the behavior of costs, which is generally accepted in accounting literature, costs are usually divided into two categories of fixed and 
variable ones in terms of changes in activity level: fixed occupants are variable. Most management accounting texts assume that unit variable costs are linear and proportional to changes in activity and that fixed costs are fixed. The proportionality and symmetry between costs and activity implies that a $1 \%$ increase in activity results in a $1 \%$ increase in costs, and a $1 \%$ decrease in activity results in a $1 \%$ decrease in costs. Stickiness might also be conditioned by existing capacity [5, 19-26].

Notions of cost behavior are a key element in management accounting [27]. There are two main views about the existence of expense stickiness: rational decisionmaking and motivational. The rational decision-making view treats expense stickiness as a consequence of management rationally choosing between alternatives after comprehensively weighting costs and benefits. The second view is motivation-based and relates expense stickiness to managerial incentives, suggesting that managers are not expected to behave as if they were in an ideal world. Among their dysfunctional behavior, perks and earnings management reflecting different contracting stimulations are often observed [28].

Planning and control are of the important tasks of management. Cost related information that managers need them to perform these tasks may be received from classified information reflected in the financial statements. The required information in this regard cannot be easily extracted from the financial statements [29]. A business entity expenses can show different behaviors suitable to the level of activity. In traditional cost model it is often assumed that administration, general and selling costs varies according to activity level. However, recent experimental studies have revealed evidence that shows that administration, general and selling costs behave asymmetrically [30]. An asymmetric behavior is a behavior in which cost increase more rapidly. In other words, the reduction in costs at the time of declining sales is lower than when the cost increases at the time of the same level of sales. This cost behavior is called cost stickiness. Expanding researches show that economic factors such as increase in assets and uncertainty about the future can have an impact on the asymmetric behavior of cost.

\section{Costs stickiness}

Cost behavior is defined as cost reaction in response to changes in activity level. Managers who understand how costs behave, have better circumstances for predicting spending trends in various operational positions. This position allows them to plan their activities and thus plan their operating revenues better. The traditional view related to costs indicates that changes in costs have a proper relationship with increased and decreased activity level. However, recent researches about costs behaviors indicate costs stickiness. Thus the degree of increase in costs level as a result of increase in activity level is higher than the degree of reduction in costs level as a result of decrease in activity level.

According to the idea of Anderson et al. [31], there are many reasons for costs stickiness. Some of these reasons include natural reluctance to lay off employees when downsizing, firm costs and the need for time to approve a reduction in the volume of activity and management decisions for maintaining used resources which could be the result of individual consideration and leads to imposing cost to the firm. By determining the stickiness of cost, the company owners can analyze whether managers incur costs to the firm or not [32].

Managers of manufacturing companies must consider the relationship of costs with income and the effect of income changes on the costs rate when planning and budgeting the company activities for predicting the future costs and thus offer a more comprehensive budget [33]. The ultimate goal of any business unit is maximizing profits and consequently, an increase in equity. Management of each profit-oriented enterprise tries to gain maximum benefit and efficiency from using the fewest resources and one of the simplest ways to reduce consumption of resources is cost control. But this requires complete knowledge of how costs behave and the factors influencing the behavior of the cost. One of the items that should be considered in the analysis of cost behavior is the phenomenon of cost stickiness. The public and dominant view is that with declining sales, costs should also be changed accordingly. But in fact, it does not happen [34].

Today, increasing competition in domestic and international markets has forced managers to better understand their cost structure and become aware of cost orientations means how the costs change. The meaning of cost orientation is a model according which costs react to changes in activity level [35]. Therefore, it is suggested that managers calculate their costs stickiness and consider all aspects of this important issue in their decisions. Orientation or the concept of cost stickiness gives a great help to investors and shareholders. Because in companies with strong stickiness, by reduced selling, costs will change more than the time when selling increases and this will be considered as a weakness of management by the investors and shareholders; while one of the main reasons of cost stickiness is bearing the current costs to avoid more losses in the future and or more profit in the future and it depends on management decisions [36]. 


\section{Review of literature}

Sustainable development refers to an economic, environmental and social development that meets the needs of the present and does not prevent future generations from fulfilling their needs. In manufacturing companies, collaboration between supply chain members is important for the sustainability and competitive advantage of a supply chain. The collaborative activities in a supply chain include various joint activities for cost reduction, research and development ( $\& \mathrm{D})$, product development, manufacturing, marketing, distribution, and service. The commitment of companies to corporate sustainability has been frequently discussed in theory and practice. Such a commitment to corporate sustainability demands a strategic approach to ensure that corporate sustainability is an integrated part of the business strategy and processes. Also, the effective adoption of continuously developing new technologies is a critical determinant of organizational competitiveness [37-41].

For the first time [5] tested the hypothesis that costs are sticky and approved the presence of stickiness in the costs behavior. They established a model with administration, general and sales costs as a function of sales, and found that costs increase by an average of $55 \%$ in response to a $1 \%$ increase in net income, but decrease only by $35 \%$ against $1 \%$ reduced income. In other words, a $1 \%$ increase in net sales, costs increase by $55 \%$ but by $1 \%$ decrease in net sales, costs decrease only by $35 \%$. Due to the lack of public information about costs related drivers, they used data of administration, general and sales costs and net income of sales for the analysis of cost stickiness, and stated that they can analyze the behavior of administration, general and sales costs based on sales net income because sales volume stimulates many parts of this cost. Subramaniam and Weidenmier Watson [25] tested the presence of behavior of stickiness in the cost price of goods sold, and the results showed a positive relationship. They also tested the effect of different economic conditions, such as rates of GDP and the different characteristics of companies, such as total assets and number of employees of companies on costs stickiness. Their results showed that in periods of economic growth, the severity of stickiness is more and in the periods that income decrease happened in its previous periods, severity of stickiness decreases. Also, by increasing the ratio of total assets to sales and an increase in the number of personnel of companies, severity of cost stickiness increases. Stickiness of sales and distribution and general and administration costs has been studied in another study by Anderson et al. [31]. The main hypothesis of this study is public sale and administration costs. After collecting data related to cost of general sales and administration and sales revenue costs of 7629 American companies in a 20-year period (1979-1998), the relationship between costs and sales was examined by multi-varibale regression relationship. The results of this study did not confirm the main hypothesis of the research and announce the general sale and administration costs of companies in the statistical population of the research, sticky.

The results obtained by Weiss [18] from a sample of 2520 out of 44,931 industrial companies from 1986 to 2005 show the issue that the sticky behavior of costs increased the accuracy of analysts in predicting revenue in total, considering the fact that prediction horizon and especial effects of industry have put this analysis under control. With regard to the classification of costs into sticky and non-sticky costs, the results of Weiss's research [18] show that the accuracy of analysts in forecasting revenues for firms with sticky cost behavior is on average 25 percent less than that of people who analyze for companies with non-sticky cost behavior. Obviously, the behavior of cost has a considerable influence on the accuracy of analysts' prediction.

In Kordestani and Mortazavi, research [30], the power of profit prediction was compared with other models by the model based on variability and stickiness of cost. The study showed that the accuracy of prediction of the model based on the variability of costs and stickiness of cost is significantly higher than the other models. In several domestic researches, stickiness of various costs has been studied. According to the results of Ghaemi and Nematollahi's research, the cost price of the sold goods and selling and distribution and general and administration costs are sticky. Another study from the same researcher showed that overhead costs are sticky, but the costs of raw materials, direct wages and financial costs are not sticky.

In other study, Khani and Shafiei [42] examined cost stickiness and its relationship with sales and the results of their research indicate an undeniable relationship between the amount of sales and company earnings with the level of company's costs. Although their findings indicate that costs do not increase in proportion to profit increase, but there is a significant relationship between them.

In other study, Banker et al. [43] examined the relationship between uncertainty and sticky behavior of cost. By examining administration, general and sales costs, number of employees and their working hours, they evaluated cost stickiness. The results indicate the presence of cost stickiness in the sample under investigation. Sepasi et al. [44] examined the characteristics of management behavior toward costs stickiness. Their studied a sample consisting 14,568 year-company and examined administration, general and sales costs for the years 1992-2011. The results showed behavioral changes in managers 
about cost stickiness so that the occurrence of cost stickiness phenomenon increases the confidence of managers.

\section{Management of strategy and strategic cost management}

Effective strategic management, plays an important role in the success of the company or organization. Increase in competition in the international arena, new technologies and changes in business processes, caused management to become more dynamic and important than before. Managers should always have a competitive attitude and for this purpose the company's competitive strategy is essential. Strategic attitude leads the manager to anticipate changes and products and their production process will be designed based on anticipated changes in demand and customer's needs. In this situation, flexibility is important.

In developed countries, most organizations use data of cost management. But the extent of their reliance on this information depends on the nature of the competitive strategy of the company. Many companies compete on the basis of the provision of goods and services at the lowest cost price. Some companies compete on the basis of being a leader in production and offering superior and differentiated products. The role of cost management is supporting corporate strategy by providing the information through which one can be successful in products development and their marketing. For achieving corporate sustainability, we suggest to use the instruments of strategic cost management in manufacturing companies. Today, managers use strategic cost management tools to accomplish strategies and achieve main success producer factors.

Instruments of strategic cost management are as below:

The most common system that used in many companies is activity-based costing system. Activity-based costing system which is specifies the resources consumed by each activity during the relevant period; and thus the cost of each activity is precisely calculated. Then the aggregated costs of any activity are assigned to the considered product or customer, depending on the product consumption or the customer use of that activity [45]. The other instrument is bench-marking. Bench-marking is a process that the companies try to choose the best practice as of the right activity in comparison with the leading companies, then given the success-builder factors, the company processes are improved to the level of performance of its competitors or even reach to a better level. For identification of internal and external failure factors in the companies, we suggest to use total quality management technique. Total quality management a new concept that emphasizes on precise measurement of the costs and identification of internal and external failure factors, through which a way to lower production (lean production) by continuous improvement in company processes is created [46].

For finding the precise systems of measurement of the cost, in-time production system and kaizen costing are useful tools for manufacturing companies. In-time production system is a system based on the volume of demand. In this system, a piece of product will be purchased or produced only when a sign of its consumer is received. This prevents the accumulation of inventory in workstations. Among the main objectives of this system we can mention improvement of quality and increase in productivity with an emphasis on the kaizen concept. Kaizen costing is a managerial technique through which managers and employees of the company become committed to perform continuous improvement program in the quality and other key factors of success. In the path of continuous improvement, the processes are re-engineered and non-value activities in the manufacturing process are removed or left behind [47].

The other instruments are target costing and value engineering. In target costing method, the costs are determined according to the product price. It means that first the companies determine the product selling prices, by analyzes of the market and then according to their expected profit, determine the cost price of the product. In other words, goal-oriented costing system is profit planning and cost management system that in that base it was the price, and the essential emphasis is on customers. Goal-oriented costing system focuses on the design stage and requires the participation of all specialized units [48]. Value engineering is suggested with the aim of examination of all activities of a project, from the formation of the first thought to the design and implementation and then setting up and utilization, is known as one of the most efficient and the most important economic methods in the field of engineering activities [49]. The purpose of value engineering is eliminating or modifying any factor that leads to the imposition of unnecessary costs, without hurting the core and essential functions of the system. Value engineering is the continuous improvement of design and implementation and it is not merely a program to reduce costs, but is a way to maximize the value of designs [50].

\section{Implementation stages of strategic cost management}

Implementation stages of strategic cost management include value chain analysis, strategic situation analysis and analysis of structural and administrative costs drivers. 


\section{Analysis of the value chain}

Value chain analysis is an instrument for strategic analysis that helps companies to better understand the competitive advantage. Value chain analysis focuses on the whole value chain of the product from design to production and after-sales service. The basic concept of analysis is that by a thorough examination of each of the activities in the value chain, one can reveal the activities that the companies have the highest or lowest success in them from competition perspective, and plan accordingly.

\section{Analysis of strategic situation}

At this stage, the company determines its potential and current competitive advantage by examining valued activities and cost drivers which have been specified in the previous stage. Companies which have competitive strategy of cost leadership are strongly trying to reduce their costs to the level of cost of cost leadership. Cost leadership focuses on cost reduction only as far as it makes sure that it is the leader in price and the holder of the lowest cost in the market. Reduction of costs is usually done by increasing productivity in the production process, distribution or general and administrative expenses. In this management strategy, maintaining stability is a priority and the company is not looking for innovation and risk-taking, but is looking for offering products and services at competitive prices. In contrast, competitive strategy of differentiation, allows the companies to raise the price of products higher than that of their competitors and without significant reduction in costs, have high profitability. These companies, by creating differentiation between the products and creating new features, make customers willing to pay a reasonable price as a result of this differentiation. Using the product differentiation strategy, one can reduce the intensity of competition and no threat of product substitution happens for the manufacturer, because all customers become loyal to the brand of the product [51-53].

\section{Analysis of drivers of structural and executory cost}

Strategic Analysis of cost drivers helps companies in improvement of their competitive situation. Drivers of structural and executory cost are used to facilitate operational and strategic decision-making.

- Driver of structural cost, has strategic nature because it includes programs and decisions which have long-term effects. In this regard, the following items are necessary to be noted:
- Scale: For example, a retail company shall determine the number of new stores it opens during the year in order to achieve the strategic goals and competitive success.

- Technology: New technologies can significantly reduce the company costs. For example, some manufacturing companies in developed countries use computer technology to show number of products that their customers use (especially large retailers), so that whenever the customers run out of the inventory in the warehouse, they send for them quickly.

- Complexity of products: companies that produce a high variety of products, have high cost of planning and management of production and also high distribution costs and after-sales service. Such companies usually use activity-based costing to determine the degree of profitability of their products.

- Administrative cost drivers, are the factors that companies can manage them in the short term through operational decisions to reduce costs. These factors include:

- Work commitment: work commitment causes reduction in costs. The companies in which there is a strong correlation between the employees, can significantly reduce their operating costs.

- Design of Production process: the sequence arrangement of equipment and the frequency of processes lead to accelerating the production process in the company. Production technology innovations can significantly reduce costs.

- Relationships with suppliers of raw materials of the company: the companies can reduce their costs significantly through agreements with suppliers of raw materials on quality, delivery time and other characteristics of their required raw materials.

\section{Conclusions}

Today, sustainability emphasizes various aspects of the organization in economic, social and environmental terms, so the importance of this issue is very important for current and future generations. Most companies have come to the conclusion that in order to improve the efficiency and effectiveness of production sustainability, they need to monitor, measure and control the characteristics of sustainable production. Therefore, measuring the sustainability of production has become an important issue in production and operations.

The purpose of this paper is to design a model for achieving a sustainable development index in order to integrate the economic, social and environmental performance data of manufacturing industries. By understanding the limitations and shortages of resources, 
the approach of the manufacturing companies includes the acquisition of new production mechanisms and technologies. To achieve newer and more innovative technologies tailored to their production processes in order to reduce production costs and increase their market share, these companies have conducted costly research. One way to deal with a shortage of resource for companies is reduce their costs. Companies regardless of sizes and operational scales must take economic opportunities into account in the long run, limiting opportunities, and incorporating innovative solutions, sustainable development, and positive social and environmental impact into their business activities.

Small-business owners face an ongoing challenge in trying to balance the need to serve customers and meet long-term business objectives while at the same time controlling the cost of doing business. A strategic cost management strategy in which cost decisions are made according to the value they add to both the business and the customer is often the most effective strategy a small business can adopt. Good financial decisions come from an effective cost management strategy designed to maximize value and minimize both initial and ongoing costs. Although a great many of a business's cost-based decisions involve purchasing, pricing and inventory management, it's also important for every small-business owner to consider costs involved inside the business.

In a competitive world, paying attention to cost management to reduce costs and increase customer satisfaction are priorities. Today, noting the proper role of the choosing quality and quantity of production factors, choosing between user processes or capital in the production process and selection of appropriate technology, in determining the cost price and producing products that meet the price reasonable in accordance with the customer' purchasing power appear more than before.

Providing the required information of cost management is possible only by establishing a modern system of management accounting including the design and use of various management accounting tools within the organization. Among these tools, there are activity-based costing, target costing, Kaizen costing, product life cycle costing. Strategic cost management is effective by accurate evaluation and identification of costs in the creation of income, profitability and value creation for companies.

By a correct understanding of their competitive situation and by using instruments of cost management, companies can reduce unnecessary costs. Also strategic cost management, by providing more accurate data for the managers, helps them in the short and long-term decision-making to achieve their strategic goals.
Given the importance of understanding the costs for those inside and outside the organization, such as managers, capital market analysts, investors and auditors recommendations for future research are presented as follows:

- Examination of the effect of the changes in sales on costs stickiness.

- Study of the relationship between management optimism with cost stickiness in various industries.

- Examination of the relationship between the cost structure with behavior of each expense.

\section{Acknowledgements \\ Not applicable. \\ Authors' contributions \\ MMR carried out this research as a first author, Dr. HJ and Professor LPD sup- ported the research as a supervisor. All authors have read and approved the manuscript.}

\section{Funding}

The authors have not received any funding from any source.

\section{Availability of data and materials \\ This paper has no associated data.}

\section{Declarations}

Ethics approval and consent to participate Not applicable.

\section{Consent to participate}

Not applicable.

\section{Competing interests}

All authors declare no conflicts of interest in this paper.

\section{Author details}

${ }^{1}$ Independent Researcher, Mashhad, Iran. ${ }^{2}$ USEK Business School, Holy Spirit University of Kaslik, PO Box 446, Jounieh, Lebanon. ${ }^{3}$ Rowe School of Business, Dalhousie University, Halifax, Canada.

Received: 9 April 2021 Accepted: 11 June 2021

Published: 16 September 2021

\section{References}

1. Rounaghi MM, Basafa S (2014) Auditing transformations in Iran, obstacles, strategies and opportunities. J Middle East Appl Sci Technol 6(10):24-31

2. Gholamzadeh Chofreh A, Ariani Goni F, Shaharoun AM, Ismail S, Jaromír Klemeš J (2014) Sustainable enterprise resource planning: imperatives and research directions. J Clean Prod 71:139-147

3. Dana LP, Rounaghi MM, Enayati G (2021) Increasing productivity and sustainability of corporate performance by using management control systems and intellectual capital accounting approach. Green Finance 3(1):1-14

4. Rounaghi MM (2019) Economic analysis of using green accounting and environmental accounting to identify environmental costs and sustainability indicators. Int J Ethics Syst 35(4):504-512

5. Anderson MC, Banker RD, Janakiraman S (2003) Are selling, general, and administrative costs "sticky"? J Acc Res 41 (1):47-63 
6. Dalla Via N, Perego P (2014) Sticky cost behavior: evidence from small and medium sized companies. Acc Finance 54(3):753-778

7. Elsayed A, Ibrahim A (2015) Economic growth and cost stickiness: evidence from Egypt. J Financ Rep Acc 13(1):119-140

8. Mellat-Parast M, Digman LA (2008) Learning: the interface of quality management and strategic alliances. Int J Prod Econ 114:820-829

9. Brüggen A, Zehnder JO (2014) SG\&A cost stickiness and equity-based executive compensation: Does empire building matter? J Manag Control 25(3-4):169-192

10. Bugeja M, Lu M, Shan Y (2015) Cost stickiness in Australia: characteristics and determinants. Aust Acc Rev 25(3):248-261

11. Guenther TW, Riehl A, Rößler R (2014) Cost stickiness: state of the art of research and implications. J Manag Control 24(4):301-318

12. Jiang W, Yao W, Hu Y (2016) The enforcement of the Minimum Wage Policy in China and firm cost stickiness. China J Acc Stud 4(3):339-355

13. Li WL, Zheng K (2017) Product market competition and cost stickiness. Rev Quant Finance Acc 49(2):283-313

14. Loy TR, Hartlieb S (2018) Have estimates of cost stickiness changed across listing cohorts? J Manag Control 29(2):161-181

15. Cheng S, Jiang W, Zeng Y (2016) Does access to capital affect cost stickiness? Evidence from China. Asia-Pac J Acc Econ 25(1-2):177-198

16. Xu J, Woo Sim J (2017) Are costs really sticky and biased? Evidence from manufacturing listed companies in China. Appl Econ 49(55):5601-5613

17. Elsayed A, Ibrahim A, Nazieh Ezat A (2017) Sticky cost behavior: evidence from Egypt. J Acc Emerg Econ 7(1):16-34

18. Weiss D (2010) Cost behavior and analysts' earnings forecasts. Acc Rev 85(4):1441-1474

19. Anderson M, Asdemir O, Tripathy A (2013) Use of precedent and antecedent information in strategic cost management. J Bus Res 66(5):643-650

20. Calleja K, Steliaros M, Thomas DC (2006) A note on cost stickiness: some international comparisons. Manag Acc Res 17:127-140

21. Liu Y, Zhang J, Zhang S, Liu G (2017) Prisoner's dilemma on behavioral choices in the presence of sticky prices: farsightedness vs. myopia. Int J Prod Econ 191:128-142

22. Mohammadi A, Taherkhani P (2016) Organizational capital, intellectual capital and cost stickiness (evidences from Iran). J Intell Capital 4:1-20

23. Noreen E (1991) Conditions under which activity-based cost systems provide relevant costs. J Manag Acc Res 3:159-168

24. Shin H, Nam Lee J, Kim D, Rhim H (2015) Strategic agility of Korean small and medium enterprises and its influence on operational and firm performance. Int J Prod Econ 168:181-196

25. Subramaniam C, Weidenmier Watson M (2016) Additional evidence on the sticky behavior of costs. Adv Manag Acc 26:275-305

26. Veldman J, Gaalman G (2014) A model of strategic product quality and process improvement incentives. Int J Prod Econ 149:202-210

27. Pamplona E, Fiirst C, de Jesus B, Silva T, da Silva C, Zonatto V (2016) Sticky costs in cost behavior of the largest companies in Brazil. Chile and Mexico Contaduría y Administración 61(4):682-704

28. Xue S, Hong Y (2016) Earnings management, corporate governance and expense stickiness. China J Acc Res 9(1):41-58

29. Elham Bakhsh H (2011) Cost stickiness and its effect on cost behavior. Master Thesis

30. Kordestani G, Mortazavi SM (2012) Identification of the determinants of stickiness of company costs. J Financ Acc Res 4(3):13-32

31. Anderson MC, Banker RD, Huang R, Janakiraman S (2007) Cost behavior and fundamental analysis of SG\&A costs. J Acc Audit Finance 22(1):1-28

32. Khaleghi Moghadam H, Karami F (2008) Prediction of profit by the model based on cost variability and stickiness. Exp Stud Financ Acc 23:19-42
33. Iranzade S, Mohammadzade Moghadam H (2010) Cost management: some evidence of behavior of cost stickiness in Iranian companies. J Manag Res 84:123-133

34. Berlo G, Moazez E, Khan Hosseini D, Nikoonesbati M (2012) Examination of the relationship between the viewpoints of management and costs stickiness in Tehran Stock Exchange. J Sci Res 3:79-95

35. Hadad Baygi SA (2012) Experimental investigation of stickiness of cost price of goods sold and operating costs and changes in the level of sales. Master Thesis, Ferdowsi University of Mashhad, Faculty of Economic and Administrative Sciences

36. Zanjirdar M, Ghafari Ashtiani P, Madahi Z (2014) Examination and analysis of factors affecting cost stickiness. Sci Res J Manag Acc 20:79-91

37. Baumgartner RJ, Rauter R (2017) Strategic perspectives of corporate sustainability management to develop a sustainable organization. J Clean Prod 140(1):81-92

38. Engert S, Rauter R, Baumgartner RJ (2016) Exploring the integration of corporate sustainability into strategic management: a literature review. J Clean Prod 112(4):2833-2850

39. Makkonen $\mathrm{H}$, Johnston $\mathrm{W}$, Javalgi $\mathrm{R}$ (2016) A behavioral approach to organizational innovation adoption. J Bus Res 69(7):2480-2489

40. Taal M, Bulatov I, Klemeš J, Stehlík P (2003) Cost estimation and energy price forecasts for economic evaluation of retrofit projects. Appl Therm Eng 23(14):1819-1835

41. Yoo SH, Rhim H, Sub Park M (2019) Sustainable waste and cost reduction strategies in a strategic buyer-supplier relationship. J Clean Prod. https:// doi.org/10.1016/j.jclepro.2019.117785

42. Khani A, Shafie H (2013) Examination of Information content of costs of general and administrative selling of companies listed in the Tehran Stock Exchange. Sci Res J 2(5):15-25

43. Banker RD, Byzalov D, Plehn-Dujowich JM (2014) Demand uncertainty and cost behavior. Acc Rev 89(3):839-865

44. Sepasi S, Fathi Z, Shaybeh S (2014) Experimental test of stickiness of costs: evidence from Tehran Stock Exchange. J Empir Res Acc 3(12):163-177

45. Nikbakht MR, Dianati Daylami Z (2013) Management accounting, 3rd edn. Ketab Mehrban Institute, pp 21-127

46. Apak S, Erol M, Elagoz I, Atmaca M (2012) The use of contemporary developments in cost accounting in strategic cost management. Procedia Soc Behav Sci 41:528-534

47. Fakharian A (2003) Cost management and value creation for shareholders. J Acc 154:43-46

48. Darabi R (2008) An approach to cost management systems. J Acc Knowl Res 15:12-75

49. Rezai Dolat Abadi H, Saleh Zadeh R, Attarpour MR, Baluei Jamkhane H (2012) Cost Management through product design: offering a combination model of target-costing methods. QFD and value engineering. J Manag Prod Oper 5:77-88

50. Pourabbas N, Borhani B (2010) Tool value engineering for cost management in the enterprise. J Ind Entrep 56:33-36

51. Noorifard $Y$, Dorostkar M (2008) The effect of cost management strategy on long-term financial performance of top companies listed on the Stock Exchange, pp 72-78

52. Ghaemi MH, Nematollahi M (2006) Examination of the behavior of sales and distribution costs and general and administration costs and cost price of goods sold in manufacturing companies listed in Tehran Stock Exchange. Exp Stud Financ Acc 16:71-90

53. Mora Cortez R, Johnston W (2019) Cultivating organizational wisdom for value innovation. J Bus Ind Mark 34(6):1171-1182 